\title{
TRANSITIONAL EXPERIENCES OF TERTIARY EDUCATION SUBSIDY GRANTEES: A QUALITATIVE STUDY
}

\author{
Helen C. Fuentes, Ph.D. \\ Assistant Professor, Eastern Samar State University, Eastern Samar, Philippines
}

Article DOI: https://doi.org/10.36713/epra8694

DOI No: $10.36713 /$ epra8694

\begin{abstract}
This is a qualitative research describing the transitional experiences of Tertiary Education Subsidy grantees in Eastern Visayas. The participants were fifteen (15) purposively selected key informants from different SUCs in Region VIII. Using thematic analysis, the results revealed that prior to inclusion to the Tertiary Education Subsidy Grant the participants experience financial difficulties in sustaining their school and household needs; as a TES grantee, participants indicated a positive impact of the grant to their family and personal economic capacity; participants reported the problems they encountered such as delayed release of fund and difficulty in the enrolment of new cash card; the grantees claimed that they were thankful for the said grant and expressed their gratitude to the government.

KEYWORDS: TES Grantees, transitional experiences, personality adjustments, subsidy
\end{abstract}

\section{INTRODUCTION}

Education is generally accepted as a public good and human right. There is no doubt that government should subsidize education. Government in various countries has aimed at providing "opportunities for everyone who aspires to higher education to attend programs appropriate to their abilities". Until now, making advanced education more accessible to poor however is a significant goal of any administration and the fundamental instrument to accomplish this goal is financing public advanced education foundations HEIs (Temple, 2009).

In the Philippines, the public higher education enrolment trends increases with the implementation of the Free Tuition Law where the student financing subsidy is provided on a far larger scale. Generally, the enrolment status of HEIs in the country decreased by $16.93 \%$ from AY 2016-2017 to AY 2017-2018, this decrease was associated with the implementation of K-12. However, an increase was recorded from AY 2017-2018 to AY 2019-2020 with the total enrolment of 2,981,803; 3,212,542; and 3,408,425 for AYs 2017-2018; 2018-2019; and 2019-2020; respectively. Moreover, the data show rising number of graduates in the last four academic years with total number of 645,973; 703,327; 751,310; and 796,576 for AYs 2017-2017; 2017-2018; 20182019; and 2019-2020; respectively (CHED Higher Education Indicators, 2020).

In 2018, the Tertiary Education Subsidy was realized through the Commission on Higher Education (CHED) Memorandum Circular No. 2018-0004. TES for Filipino students being one of the five components of RA No. 10931 is directed by the UniFAST Board and the implementers of the program are SUCs and select LUCs. The Tertiary Education Subsidy was set up for all Filipino students who took on undergraduate-postsecondary secondary programs of SUCs and LUCs private and all TVIs. The TES is the initiative of the Philippine government to provide poor but capable students with access to higher education. It intends to raise the quantity of advanced education graduates among financially disable families through direct arrangement of financing for their schooling. A TES grantee gets a yearly subsidy of Php40,000 altogether. This incorporates Php2,500 per semester for course books and other learning materials and Php3,500 each month for 10 month time as allowance. It is then the main purpose of the study to describe the transitional experiences of the TES grantees in Eastern Visayas.

\section{METHODS}

This study utilized thematic analysis as the method of analyzing qualitative data. The participants were purposively selected from six (6) out of 10 State Universities in the Eastern Visayas Region, Philippines. These 
institutions were selected because of their strategic locations in the region and based on the number of TES grantees enrolled in the main campus.

Table 1. Number of Respondents

\begin{tabular}{cc}
\hline \hline $\begin{array}{c}\text { SUCs } \\
\text { (Main Campus) }\end{array}$ & $\begin{array}{c}\text { No. of KII } \\
\text { Respondents }\end{array}$ \\
\hline State University 1 & 2 \\
State University 2 & 2 \\
State University 3 & 2 \\
State University 4 & 2 \\
State University 5 & 3 \\
State University 6 & 4 \\
\hline Total & $\mathbf{1 5}$ \\
\hline
\end{tabular}

Utilizing the purposive sampling, the key informants were selected from the first batch of TES grantees in the region or those who have been a grantee for three (3) academic years. The sample size was not predetermined. Data gathering continues until data reaches the saturation point, that is, the stage wherein further observations and interviews add little or nothing to the codes identified by the researcher (Vincze, 2010). The instrument of Maranda et al. (2016) which includes open-ended questions that are intended to assist the TES grantees in expressing their experiences and the problems that they may have encountered on being a TES grantee. However, in an instance that a respondent was not able to attend the call, the interview was done through exchange of messages through messenger or exchange of emails between the respondent and the researcher. The interview transcripts were analyzed using thematic analysis method.

\section{Ethical Consideration}

In trying to ensure that the study adheres to acceptable ethical standards, the following considerations were followed: (1) Consent form was administered to respondents before formally starting with the data gathering; (2) Anonymity was observed while obtaining relevant information. This is done to assure the respondents that all information extracted from them remain confidential; (3) Respondents were informed of their participation in the study and the type of data to be obtained from them; (4) Respondents' consent was secured on the condition that all information derived from the questionnaires and their participation in full volition will not in any ways incur harm or pose any type of risks; and (5) The University Research Ethics Committee approved this study (Approval Reference Number 009-21-GS).

\section{RESULTS AND DISCUSSION}

The final organization presented in Table 2 defines a total of 18 codes, 7 categories within the three themes: (1) pre-TES grant struggles; (2) the experience as TES grantee; and (3) attitude toward the scholarship grant.

\section{Pre-Tertiary Education Subsidy Grant Struggles}

Participants described their experiences prior to inclusion to the Tertiary Education Subsidy grant based on their perceptions on the economic status of their family and as a student (SC: "economically deprived households and financial difficulties of the student). Thus, all (15) participants believed that their family have unstable income to support their daily needs. For example, the grantees affirmed:

KI 1: "During my first year in college, it was very hard for me due to financial difficulties. Though it was already free tuition it was very hard for my family to support me with the miscellaneous fees. In my pocket, I have only 300 pesos allowance per week less the fare, rice, and viand. I don't have any more allowance for my school needs. It was really a big burden to my parents. Our family income is not enough for our family necessities"

KI 6: "Being a non-TES grantee was very hard for me and my parents. I experienced going to school with money that is only used for my fare from home to school and vice versa. My parents are struggling with our financial needs."

KI 7: "Being a non-TES I struggles a lot since my father is a farmer and my mother is a housewife they didn't give me any money for my studies because the money that they make from copra is not enough." 
KI 9: "My parents and my older brother don't have a stable income that will suffice and support our daily needs." needs, like:

Further, six (6) grantees felt that reliance on farming and selling of root crops cannot sustain their

KI 3: "The income in farming is not sufficient enough to buy and support our daily needs and most especially our educational necessities."

KI 4: "In fact, my parents are relying on farming root crops like kamote (sweet potato) and sell them during tabo (market day) every Friday at the town market."

KI 10: "Farming root crops is seasonal. So, it was hard for us to save money."

As many as ten (15) shared that financial difficulty of student leads to giving up of dreams and aspirations and on the other side it made them strived to earn an income to support their studies. The grantees affirmed:

KI 1: "I worked as house helper at Tacloban for me to save money so that I can enroll in the opening of classes. After a month I went home for the school enrollment and I am happy that I had provided the things I need in the first month of my schooling."

KI 2: "When I was a non-TES grantee I experience financial hardships for my studies."

KI 5: "It was difficult for me to ask money for my school needs knowing the situation of my family.

KI 6: "Before being a TES grantee, I usually work during weekends for my allowance, my allowance was just enough to provide my personal and school necessities"

KI 8: "There comes a time that I and my parents are at the verge of giving up our dreams and aspirations. Even a single sheet of paper contains tears and sweats."

The statements of the participants focused on their economic instability prior to the inclusion to the said grant. These evolved from being a member of an economically deprived household which affect their financial capacity to pursue tertiary education. However, a positive response was remarkable - a participant who claimed that financial constraints will not hinder in achieving goals instead one should strive to earn income, the participant elaborated that having an earning to sustain personal and school needs is the true meaning of success. This statement conforms to the findings of Nnamani et al. (2014) that self-sponsored students are more satisfied with their academic performance than those that get money either from their parents or from a scholarship fund.

\section{The Experience as TES Grantee}

In the transcripts, the grantees also focused on their experiences as TES grantees (C: experience as TES grantee). All participants indicated a positive effect of the TES grant to their family, four (4) considered it as a blessing while six (6) expressed that it helps the financial capacity of their family. For example:

KI 1: "It was a blessing and good news to my family. My parents will no longer be indebted with money from their friends."

KI 6: "TES doesn't just support me but my whole family as well."

KI 7: "With the subsidy I can help my younger siblings with their allowances and school needs."

The grant has positive effects to the participants. It brought various experiences to the grantees as a source of hope, that boosted their confidence and enhanced financial management skills, the grantees affirmed:

KI 1: "Indeed, Tertiary Education Subsidy (TES) was a great help for me and my family. I can buy books, food, pay my boarding house in advance and I am no longer afraid in attaining my dreams."

KI 2: "I experienced to withdraw money in a bank for the first time and most of all I 
learned how to handle my finance right.

KI 3: "It really help me and my family a lot, it also helps my sisters and brothers who is still studying. It makes my studies easy because I can now buy things and pay for my studies."

KI 4: "Now as a TES grantee, I was able to experience things like having my own laptop which helps me a lot in doing my school works easier."

KI 6: "This is a big help to me, it helps with school fees and I can buy your school supplies in addition to your daily allowance it is a big help especially to my parents because of this TES, we fixed also our house little by little."

KI 8: "I have the guts to pursue college."

KI 9: "I get to have an ATM card for the first time."

Table 2. The process of data abstraction contained in grantees' interview transcripts

\begin{tabular}{|c|c|c|c|}
\hline & hemes & Categories & $\begin{array}{c}\text { Codes (Frequency } \\
\text { of Statements) }\end{array}$ \\
\hline \multirow{4}{*}{$\begin{array}{l}\text { Pre-TES Grant } \\
\text { Struggles }\end{array}$} & \multirow{2}{*}{$\begin{array}{l}\text { Economically deprived } \\
\text { households }\end{array}$} & Unstable income to support the daily needs & $(10)$ \\
\hline & & $\begin{array}{l}\text { Reliance on farming and selling of root crops cannot } \\
\text { sustain their needs }\end{array}$ & $(6)$ \\
\hline & \multirow{2}{*}{$\begin{array}{l}\text { Financial Difficulties } \\
\text { of the Student }\end{array}$} & Giving up dreams and aspirations & $(3)$ \\
\hline & & Strive to earn an income for studies & $(10)$ \\
\hline \multirow{9}{*}{$\begin{array}{l}\text { The experience as } \\
\text { TES Grantee }\end{array}$} & \multirow{2}{*}{$\begin{array}{l}\text { Impact of the Grant to } \\
\text { the Family }\end{array}$} & A blessing to the family & $(4)$ \\
\hline & & Helps financial capacity & $(6)$ \\
\hline & \multirow{5}{*}{$\begin{array}{l}\text { Impact of the Grant to } \\
\text { the Student }\end{array}$} & The scholarship grant is a source of hope & $(5)$ \\
\hline & & Got an ATM card for the first time & $(8)$ \\
\hline & & Withdraw money in the bank for the first time & (8) \\
\hline & & Learn how to manage finances & (3) \\
\hline & & Boost confidence and capacity to meet needs & $(7)$ \\
\hline & \multirow{2}{*}{$\begin{array}{l}\text { Problems Encountered } \\
\text { regarding the Grant }\end{array}$} & Delay in releasing funds & (3) \\
\hline & & Difficulty in enrolment for new cash card & $(2)$ \\
\hline \multirow{5}{*}{$\begin{array}{l}\text { Attitude towards the } \\
\text { TES Grant }\end{array}$} & \multirow{2}{*}{ Gratitude } & Thankful to government & $(8)$ \\
\hline & & Thankful to the university & $(8)$ \\
\hline & \multirow{3}{*}{ Value } & Optimistic & $(10)$ \\
\hline & & A motivation to focus on study & $(5)$ \\
\hline & & $\begin{array}{l}\text { Giving importance to the opportunity to study in a } \\
\text { university }\end{array}$ & $(8)$ \\
\hline
\end{tabular}

On the other hand, five (5) participants reported about the TES-related problems they encountered such as delayed release of fund (3) and difficulty in the enrolment of new cash card (3).

KI 8: "Sometimes the delay of allowance makes me worry of my pending class requirements fees. Especially in this time of pandemic, we really need to buy load weekly for our study."

KI 9: "I find difficulty in enrolling for the new cash card."

Participants described their experiences in the context of impact to the family, themselves as student grantee, and the TES-related problems encountered. Thus, some participants have first time experiences on having an ATM and chance to withdraw in the bank. On the other hand, five participants said that the scholarship grant is a source of hope while seven claimed that the grant boosted their confidence. This is supported with the findings of Yutong (2013) that financial aid has positive effect not only on GPA but influence the outcomes of low-income students and could ultimately encourage them to have higher achievement. 


\section{Attitude towards the Tertiary Education Subsidy}

Furthermore, the grantees claimed that they recognize and give value to this government subsidy (C: attitude towards the TES grant). They expressed their gratitude to the government and to their university as well.

KI 3: "I am very honored and thankful to TES for the help and support in my studies. It means so much to me and I find it hard to express my gratitude."

KI 4: "Through this program, thousands of aspiring students like me are encouraged to have a better view in life and value education for the brighter future ahead of us."

KI 5: "I greatly appreciate the generous financial support coming from TES and the opportunity to pursue both my educational and extracurricular dreams."

KI 6: "Nevertheless, poverty showed me the worth of education and how being a degree holder will change my life."

KI 9: "It has been a huge relief to get a grant the prioritize lifting the financial burden of every students. I am very honored and grateful as a beneficiary of TES grants."

KI 10: "Finally, I will graduate with the support of TES and I am filled with gratitude with that TES was the best grant that I received in my entire college life. I would like to thank the government and our institution for this scholarship grant. I promise to work harder and be a good citizen as my way of giving back to the country."

Interestingly, the participants claimed that they were thankful and expressed their gratitude to the persons behind the Republic Act No. 10931 particularly the Tertiary Education Subsidy. Some participants claimed that TES grant motivated them to study harder since they were lucky to be chosen as TES grantee. This claim is in consonance to the statement of $\mathrm{Li}$ (2014) that majority of low-income students have increased their GPA once they received financial aid.

\section{CONCLUSIONS}

Based on the conditions under which this study was conducted and the foregoing findings, the following conclusions were drawn: prior to the inclusion to Tertiary Education Subsidy the participants struggled to sustain their school needs, the Tertiary Education Subsidy brought positive experience on the family and the grantee particularly, the TES grantees were thankful and they expressed their gratitude for policy-makers and TES implementers. It also increased the participants' interest to finish tertiary education.

\section{REFERENCES}

1. Bernardo, A. B., \& Resurreccion, K. F. (2018). Financial stress and well-being of Filipino students: The moderating role of external locus of-hope. Philippine Journal of Psychology, 51(1), 33-61.

2. Commission on Higher Education. (2020). Higher Education Facts and Figures. https://ched.gov.ph/2020-highereducation-facts-and-figures/. Retrieved April 15, 2021.

3. $L i$, S. (2014). Investigating the impact of financial aid on four-year college enrollment among college-qualified students.

4. Lim, M. A., Lomer, S., \& Millora, C. (2018). Universal Access to Quality Tertiary Education in the Philippines. International Higher Education, 94, 19-21. https://doi.org/10.6017/ihe.2018.0.10563

5. Maranda, A., Escalona, O., Sansona, A., \& Maranda, J. (2016). Assessing the delayed gratification, identity orientation and transitional plans of ESGP-PA recipients: Implications for policies and program development. Journal of Government and Politics, 40(10), 493-515.

6. Nnamani, C. N., Dikko, H. G., \& Kinta, L. M. (2014). Impact of students' financial strength on their academic performance: Kaduna Polytechnic experience. African Research Review, 8(1), 83-98.

7. O'Donoghue T, Rabin M (2000). The economics of immediate gratification. J Behav Decis Mak 13: 233-250.

8. Republic Act No. 10687. 2015. Unified Student Financial Assistance System for Tertiary Education (UniFAST) Act. Quezon City: Congress of the Philippines.

9. Republic Act No. 10931. 2017. Implementing Rules and Regulations. Universal access to quality tertiary education act. Quezon City: Congress of the Philippines.

10. Temple, S. L. (2009). Factors that influence students' desires to attend higher education. Seton Hall University, 141.

11. Vincze, Z. (2010). Grounded theory. In Mills, A. J., G. Durepos, \& E. Wiebe, E. (Eds.). Encyclopedia of case study research, 429-432. Thousand Oaks, CA: Sage

12. Yutong, Po (2013). Need-Based Financial Aid and Student Success in XX College in Central China. Reprosentralen, Universiteteti Oslo. 